\title{
Increase of Caspase-3 Activity by Lignans from Machilus thunbergii in HL-60 Cells
}

\author{
Bo-Young PArK, ${ }^{a}$ Byung-Sun Min, ${ }^{a}$ Ok-Kyoung Kwon, ${ }^{a}$ Sei-Ryang OH, ${ }^{a}$ Kyung-Seop AhN, ${ }^{a}$ \\ Tae-Jin KIM, ${ }^{a}$ Doo-Young KIM, ${ }^{a}$ KiWhan BAE, ${ }^{b}$ and Hyeong-Kyu LEE*, \\ ${ }^{a}$ Korea Research Institute of Bioscience and Biotechnology; Daejeon 305-333, Korea: and ${ }^{b}$ College of Pharmacy, \\ Chungnam National University; Daejeon 305-764, Korea. Received January 15, 2004; accepted April 20, 2004
}

\begin{abstract}
Nine lignans and two butanolides were isolated from the stem bark of Machilus thunbergii and their structures were identified as machilin A (1), licarin B (2), zuonin B (3), macelignan (4), secoisolancifolide (5), isolancifolide (6), oleiferin C (7), meso-dihydroguaiaretic acid (8), licarin A (9), machilin F (10), and nectandrin B (11) by spectroscopic means. These compounds were assessed for their abilities to activate a caspase-3 activity in human promyeloid leukemic HL-60 cells. The intracellular caspase-3 activity of macelignan (4), oleiferin C (7), meso-dihydroguaiaretic acid (8), and licarin A (9) increased approximately 3.04, 6.16, 2.10, and 3.10-fold at $100 \mu_{\mathrm{M}}$ over that of untreated control. In addition, compounds 4, 7, 8, and 9 induced internucleosomal DNA fragmentation in HL-60 cells.
\end{abstract}

Key words Machilus thunbergii; lignan; caspase-3; DNA fragmentation; apoptosis

Apoptosis is a form of cell death that occurs during several pathologic situations in organisms and contributes to cell replacement, tissue remodeling, and removal of damaged cells under normal conditions. ${ }^{1)}$ However, inappropriate regulation of apoptosis may cause many serious disorders, such as neural generation, AIDS, autoimmune disease, and cancers. In numerous studies it has been documented that the process of apoptosis is regulated by the expression of several proteins. Of these, the caspases make up a family of cysteine proteases that cleave substrates after aspartic residue. These proteins are considered to play a central role in the apoptotic process and to trigger a cascade of proteolytic cleavage in mammalian cells. Of particular interest is caspase-3, the most widely studied member of the caspase family and one of the key executioners of apoptosis, being responsible either partially or wholly for the proteolytic cleavage of various proteins. $^{2,3)}$

The stem bark of Machilus thunbergii SiEB. et Zucc. (Lauraceae) is one of the well-known medicinal herbs used to treat a wide variety of diseases including edema, abdominal pain, and abdominal distension. ${ }^{4}$ Lignans, lignan glycosides, alkaloids, flavonoids, and essential oils have been reported from this plant. ${ }^{5}$ Some lignans from $M$. thunbergii have been shown to have potent antioxidant activity. ${ }^{6}$ In addition, Kim and Ryu reported that butanolides from $M$. thunbergii have an inhibitory effect on nitric oxide synthesis in activated macrophages. ${ }^{7)}$ During the course of our search for new caspase-3 activators from natural sources, we found that a $\mathrm{MeOH}$ extract of the stem bark of $M$. thunbergii showed activity. In this study we describe the increase of caspase- 3 activity and internucleosomal DNA fragmentation of compounds from this source.

\section{MATERIALS AND METHODS}

Plant Material The stem bark of $M$. thunbergii was collected during September 2001 at Ulleung-Do, Kyungbook, Korea, and dried at room temperature. A voucher specimen (PB-2910) is deposited at the Plant Extract Bank, Korea Research Institute of Bioscience and Biotechnology, Daejeon, Korea.
Chemicals RPMI 1640 medium and fetal bovine serum (FBS) were purchased from Gibco Laboratories. Ac-AspGlu-Val-Asp 7-amino-4-trifluoromethyl coumarin (AcDEVD-AFC) was obtained from Enzyme Systems Products (Livermore, CA, U.S.A.). Camptothecin, penicillin, streptomycin, trypan blue, 3-(4,5-dimethylthiazol-2-yl)-2,5-diphenyltetrazolium (MTT), propidium iodide (PI), and HEPES were obtained from Sigma Chemical Co. (St. Louis, MO, U.S.A.).

Extraction and Isolation Stem bark of $M$. thunbergii $(1.8 \mathrm{~kg})$ was extracted with $\mathrm{MeOH}$ at room temperature to give a dark-brown extract $(290 \mathrm{~g})$. The $\mathrm{MeOH}$ extract was suspended in $\mathrm{H}_{2} \mathrm{O}$ and extracted with hexane to give a hexane-soluble fraction $\left(35.3 \mathrm{~g}\right.$ ). The resulting $\mathrm{H}_{2} \mathrm{O}$ layer was extracted with $\mathrm{CHCl}_{3}$ and EtOAc to yield a $\mathrm{CHCl}_{3}$-soluble fraction $(2.7 \mathrm{~g})$ and an EtOAc-soluble fraction $(68.1 \mathrm{~g})$, respectively. The hexane-soluble fraction was chromatographed on a column of silica gel $(500 \mathrm{~g})$. The column was eluted using a gradient of hexane and acetone to give four fractions. Repeated column chromatography of Fr. $2(10.9 \mathrm{~g})$ on silica gel (hexane/acetone; 7:3 and benzene/EtOAc; $20: 1)$ and ODS column $(\mathrm{MeOH}, 10 \%$ aq. $\mathrm{MeOH})$ afforded compounds 1 (146 mg), 2 (26 mg), 3 (75 mg), 4 (147 mg), 5 (26 mg), 6 (32 mg), and 7 (7 mg). Repeated column chromatography of Fr. 3 on silica gel (hexane/EtOAc; 5:3, benzene/acetone; $30: 1$, and $\mathrm{CHCl}_{3} /$ EtOAc; $5: 1)$ and ODS column (15\% aq. $\mathrm{MeOH})$ furnished compounds $8(147 \mathrm{mg}), 9(27 \mathrm{mg}), \mathbf{1 0}(25 \mathrm{mg})$, and $\mathbf{1 1}$ (62 mg).

Machilin A (1): Colorless needles; mp $66-67^{\circ} \mathrm{C} ;[\alpha]_{\mathrm{D}} 0^{\circ}$ $\left(c=0.53, \mathrm{CHCl}_{3}\right) ; \mathrm{UV} \lambda_{\text {max }}\left(\mathrm{CHCl}_{3}\right) \mathrm{nm}(\log \varepsilon): 264$ (2.46); FAB-MS $m / z: 325[\mathrm{M}-\mathrm{H}]^{+}$.

Licarin B (2): White amorphous powder; $[\alpha]_{\mathrm{D}}-50.8^{\circ}$ $\left(c=0.25, \mathrm{CHCl}_{3}\right) ; \mathrm{UV} \lambda_{\text {max }}\left(\mathrm{CHCl}_{3}\right) \mathrm{nm}(\log \varepsilon): 273$ (2.56); FAB-MS $m / z: 324[\mathrm{M}]^{+}$.

Zuonin B (3): Colorless needles; $\mathrm{mp} 49-51^{\circ} \mathrm{C} ;[\alpha]_{\mathrm{D}} 0^{\circ}$ $\left(c=0.33, \mathrm{CHCl}_{3}\right) ; \mathrm{UV} \lambda_{\text {max }}\left(\mathrm{CHCl}_{3}\right) \mathrm{nm}(\log \varepsilon): 294$ (2.45); FAB-MS $m / z: 363[\mathrm{M}+\mathrm{Na}]^{+}$.

Macelignan (4): Yellow oil; $[\alpha]_{\mathrm{D}}+4.8^{\circ}\left(c=0.1, \mathrm{CHCl}_{3}\right)$; $\mathrm{UV} \lambda_{\max }\left(\mathrm{CHCl}_{3}\right) \mathrm{nm}(\log \varepsilon): 302$ (2.62), 274 (2.60); FABMS $m / z: 327[\mathrm{M}-\mathrm{H}]^{+}$. 
Secoisolancifolide (5): Colorless oil; $[\alpha]_{\mathrm{D}}+75.0^{\circ}(c=0.2$, $\left.\mathrm{CHCl}_{3}\right)$; UV $\lambda_{\text {max }}\left(\mathrm{CHCl}_{3}\right) \mathrm{nm}(\log \varepsilon): 259$ (2.35); FAB-MS $m / z: 283[\mathrm{M}-\mathrm{H}]^{+}$.

Isolancifolide (6): Colorless oil; $[\alpha]_{\mathrm{D}}-69.0^{\circ}(c=0.13$, $\left.\mathrm{CHCl}_{3}\right) ; \mathrm{UV} \lambda_{\text {max }}\left(\mathrm{CHCl}_{3}\right) \mathrm{nm}(\log \varepsilon): 258$ (2.41); FAB-MS $m / z: 251[\mathrm{M}-\mathrm{H}]^{+}$.

Oleiferin C (7): Colorless oil; $[\alpha]_{\mathrm{D}}+40.0^{\circ} \quad(c=0.5$, $\left.\mathrm{CHCl}_{3}\right) ; \mathrm{UV} \lambda_{\max }\left(\mathrm{CHCl}_{3}\right) \mathrm{nm}(\log \varepsilon): 251$ (3.01), 285 (3.09); FAB-MS $m / z: 341[\mathrm{M}-\mathrm{H}]^{+}$.

meso-Dihydroguaiaretic Acid (8): White amorphous powder; $[\alpha]_{\mathrm{D}} 0^{\circ}\left(c=0.47, \mathrm{CHCl}_{3}\right) ; \mathrm{UV} \lambda_{\max }\left(\mathrm{CHCl}_{3}\right) \mathrm{nm}(\log \varepsilon)$ : 250 (2.89), 276 (3.00); FAB-MS $m / z: 330[\mathrm{M}]^{+}$.

Licarin A (9): White amorphous powder; $[\alpha]_{\mathrm{D}}-26^{\circ}$ $\left(c=0.34, \mathrm{CHCl}_{3}\right) ; \mathrm{UV} \lambda_{\max }\left(\mathrm{CHCl}_{3}\right) \mathrm{nm}(\log \varepsilon): 277$ (2.80); FAB-MS $m / z: 326[\mathrm{M}]^{+}$.

Machilin F (10): Yellow oil; $[\alpha]_{\mathrm{D}}+2.3^{\circ}\left(c=0.2, \mathrm{CHCl}_{3}\right)$; $\mathrm{UV} \lambda_{\max }\left(\mathrm{CHCl}_{3}\right) \mathrm{nm}(\log \varepsilon): 296$ (2.64); FAB-MS $m / z: 342$ $[\mathrm{M}]^{+}$.

Nectandrin B (11): Yellow oil; $[\alpha]_{\mathrm{D}} 0^{\circ}\left(c=0.05, \mathrm{CHCl}_{3}\right)$; $\mathrm{UV} \lambda_{\max }\left(\mathrm{CHCl}_{3}\right) \mathrm{nm}(\log \varepsilon): 285$ (2.54); FAB-MS $m / z: 344$ $[\mathrm{M}]^{+}$.

Cell Culture Human promyelocytic leukemia HL-60 cells were obtained from the American Type Culture Collection (ATCC). The cells were cultured in IMDM medium supplemented with $20 \%$ fetal bovine serum, $100 \mathrm{IU} / \mathrm{ml}$ penicillin and $100 \mu \mathrm{g} / \mathrm{ml}$ streptomycin. The cell culture was maintained at $37{ }^{\circ} \mathrm{C}$ in a $5 \% \mathrm{CO}_{2}$ humidified incubator.

Cell Viability Cell viability was assessed by the standard MTT technique. Cells were seeded to a concentration of $5 \times 10^{5}$ cells $/ \mathrm{ml}$, then compounds $\mathbf{1}-\mathbf{1 1}$ were added to the suspension. After $24 \mathrm{~h}$ incubation $\left(37^{\circ} \mathrm{C}\right), 10 \mu \mathrm{l}$ MTT $(5 \mathrm{mg} / \mathrm{ml})$ was added to each well. After $4 \mathrm{~h}$ incubation $\left(37^{\circ} \mathrm{C}\right)$ and $5 \mathrm{~min}$ centrifugation $(3000 \mathrm{rpm})$, the resulting formazan precipitate was dissolved with $100 \mu \mathrm{l}$ DMSO and the absorption was measured at $570 \mathrm{~nm}$ on a microplate reader (BIO-RAD, U.S.A.). ${ }^{8}$ The growth inhibition was determined using;

growth inhibition $=($ control's OD - sample's OD $) /$ control's OD

Assay of Caspase-3 Activity Caspase-3 enzyme activity was measured by proteolytic cleavage of the fluorogenic substrate Ac-DEVD-AFC by counting on a microplate fluorometer (Perkin-Elmer, LS50B, U.S.A.). After incubation with $100 \mu \mathrm{M}$ compounds $\mathbf{1}-\mathbf{1 1}$ for $16 \mathrm{~h}$, cells were harvested and washed once with cold PBS. The pellets were lysed using $15 \mu \mathrm{l}$ of lysis buffer containing $10 \mathrm{~mm}$ EDTA, $0.5 \%$ Triton X100 , and $10 \mathrm{~mm}$ Tris- $\mathrm{HCl}(\mathrm{pH} 8.0)$ at room temperature for $10 \mathrm{~min}$, and then $100 \mu \mathrm{l}$ of assay buffer (100 mM HEPES; $\mathrm{pH}$ 7.5, $10 \mathrm{~mm}$ dithiothreitol, $10 \%$ sucrose, $0.1 \%$ CHAPS, $0.1 \%$ BSA) and $10 \mu \mathrm{l}$ of substrate solution $(10 \mu \mathrm{l}$ of $20 \mathrm{~mm}$ substrate $+1000 \mu 1$ assay buffer) were added on ice. Fluoroscene at $400 \mathrm{~nm}$ (excitation) and $505 \mathrm{~nm}$ (emission) was measured after incubation at $37^{\circ} \mathrm{C}$ for $1 \mathrm{~h} .{ }^{9)}$

DNA Fragmentation After incubation with compounds 4, 7-9 (at $100 \mu \mathrm{M}$ ) for $16 \mathrm{~h}$, HL-60 cells were harvested and washed with PBS. Apoptotic DNA was purified using an Apoptotic DNA Ladder Kit (Roche, Mannleim, Germany). Then cell pellets were lysed in $200 \mu \mathrm{l}$ of lysis buffer $(10 \mathrm{~mm}$ Tris-HCl; $\mathrm{pH}$ 8.0, $10 \mathrm{~mm}$ Urea, $6 \mathrm{~m}$ guanidine- $\mathrm{HCl}$, and $20 \%$ Triton X-100; $\mathrm{pH} 4.4$ ) for $10 \mathrm{~min}$. The lysate flowed to the filter and the filter was washed with $4 \mathrm{~mm} \mathrm{NaCl}, 0.4 \mathrm{~mm}$
Tris- $\mathrm{HCl}(\mathrm{pH} \mathrm{7.5)}$ and $80 \%$ EtOH. The DNA bound at the filter was eluted with $200 \mu$ l elution buffer ( $10 \mathrm{~nm}$ Tris- $\mathrm{HCl}$, $\mathrm{pH}$ 8.5). The isolated DNA fragments were separated by $1 \%$ agarose gel containing $0.5 \mu \mathrm{g} / \mathrm{ml}$ of ethidium bromide and analyzed under an ultraviolet illuminator. ${ }^{10)}$

\section{RESULTS AND DISCUSSION}

As part of the ongoing program of research in our laboratory to detect natural products by the increase of caspase- 3 activation, the activated properties of compounds from the stem bark of M. thunbergii were investigated. Repeated column chromatography of the hexane-soluble fraction of the $\mathrm{MeOH}$ extract of $M$. thunbergii on silica gel and ODS led to the isolation of nine lignans $(\mathbf{1}-\mathbf{4}, \mathbf{7}-\mathbf{1 1})$ and two butanolides $(\mathbf{5}, \mathbf{6})$. These compounds were identified as machilin A (1), licarin B (2), zuonin B (3), macelignan (4), secoisolancifolide (5), isolancifolide (6), oleiferin $\mathrm{C}(\mathbf{7})$, meso-dihydroguaiaretic acid (8), licarin A (9), machilin F (10), and nectandrin B (11) by comparing their spectral data to those previously reported (Fig. 1). ${ }^{11-16)}$

The compounds 1-11 isolated were tested for their increasing activity of caspase-3 enzyme in human promyelocytic leukemia HL-60 cells (doubling time; about $24 \mathrm{~h}$ ) for $16 \mathrm{~h}$. After $16 \mathrm{~h}$ of exposure of compounds (1-11) from $M$. thunbergii at $100 \mu \mathrm{M}$, macelignan (4), oleiferin C (7), mesodihydroguaiaretic acid (8), and licarin A (9) were significantly increased to a level approximately $3.04,6.16,2.10$, and 3.10-fold that of the non-treated control (Fig. 2). HL-60 cells exhibited typical morphological changes of apoptosis after treatment with compounds $4,7-9$. On the other hand, compounds $\mathbf{1}-\mathbf{3}, \mathbf{5}, \mathbf{6}, \mathbf{1 0}$, and $\mathbf{1 1}$ showed cytotoxic activity at $100 \mu \mathrm{m}$ and were inactive for caspase- 3 activation. In the structure-activity relationship of lignans from $M$. thunbergii, the dibenzylbutanedimethyl lignans $(4,7,8)$ showed more potent increasing activity of caspase-3 than neolignans $(\mathbf{2}, \mathbf{9})$

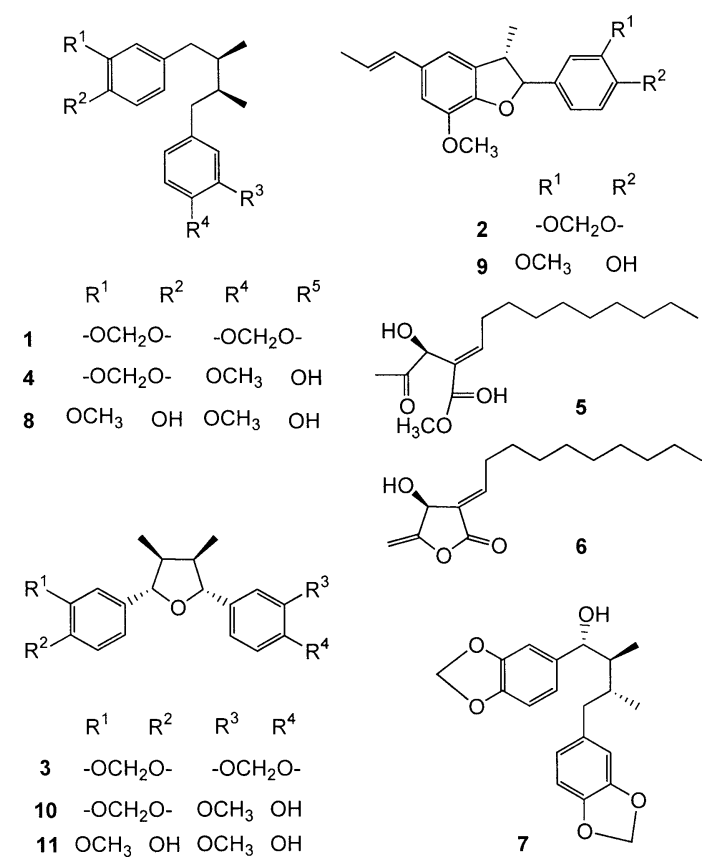

Fig. 1. Chemical Structures of Compounds 1-11 Isolated from M. thunbergii 


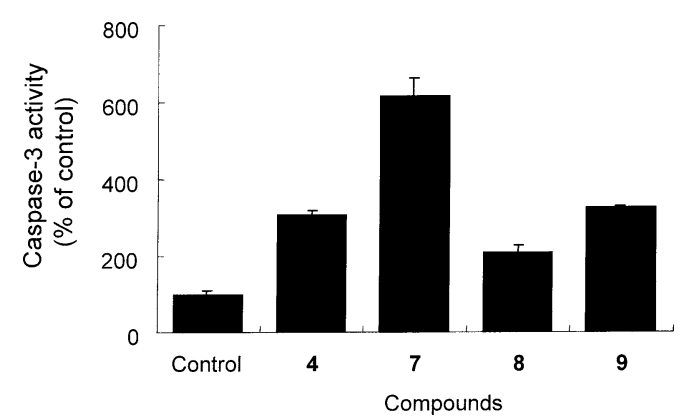

Fig. 2. Effect of Macelignan (4), Oleiferin C (7), meso-Dihydroguaiaretic Acid (8), and Licarin A (9) on Caspase-3 Activation

HL-60 cells were treated with compounds $4,7-9$ at $100 \mu \mathrm{M}$ for $16 \mathrm{~h}$, then collected and washed with PBS. Cell lysate was incubated at $37^{\circ} \mathrm{C}$ with Ac-DEVD-AFC for $1 \mathrm{~h}$, after which the fluroscence intensity was measured.

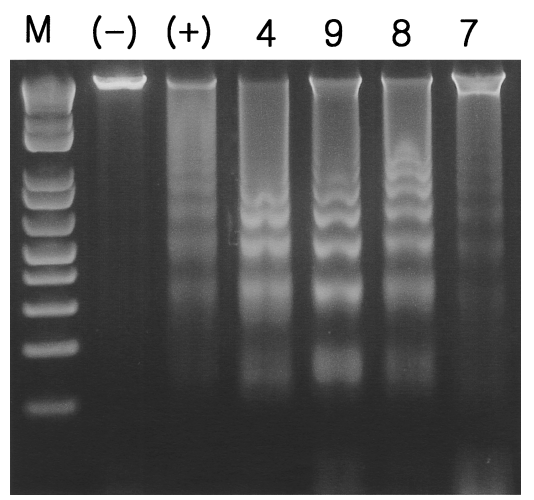

Fig. 3. DNA Fragmentation Induced by Macelignan (4), Oleiferin C (7), meso-Dihydroguaiaretic Acid (8), and Licarin A (9)

HL-60 cells were treated with compounds 4, 7-9 for $16 \mathrm{~h}$ and then collected. DNA fragmentation of treated cells was detected by $1 \%$ agarose gel electrophoresis. $\mathrm{M}$ is a DNA size marker.

or tetrahydrofuran lignans $(\mathbf{3}, \mathbf{1 0}, \mathbf{1 1})$. Of the compounds tested, oleiferin C (7) was found to have the greatest increase of caspase- 3 activation. Our results suggest that a hydroxyl group on butane moiety of dibenzylbutanedimethyl seems to significantly enhance caspase-3 activity.

Apoptosis involves the activation of endonucleases and this activation results in the cleavage of genomic DNA into a characteristic ladder pattern. ${ }^{17)}$ The proteolytic activity was due to caspase-3. ${ }^{18)}$ To provide evidence supporting the involvement of apoptosis, a DNA fragmentation assay was performed. HL-60 cells treated with compounds 4, 7-9 at $100 \mu \mathrm{M}$ for $16 \mathrm{~h}$ showed the distinctive ladder pattern charac- teristic of apoptosis (Fig. 3).

In summary, the results of the present study demonstrated that macelignan (4), oleiferin $\mathrm{C}$ (7), meso-dihydroguaiaretic acid (8), and licarin A (9) induce an apoptotic effect in HL60 cells in a caspase- 3 activation manner. It is possible that these compounds may be valuable as cancer chemopreventive agents.

Acknowledgments This research was supported by a grant (PF0300401-00) from the Plant Diversity Research Center of the $21 \mathrm{st}$ Century Frontier Research Program funded by the Ministry of Science and Technology of the Korean government. We are grateful to the Korea Basic Science Institute, Daejeon, Korea, for NMR and mass spectral measurements.

\section{REFERENCES}

1) DeLong M. J., Ann. N. Y. Acad. Sci., 842, 82-90 (1988).

2) Kim E. H., Jang M. H., Shin M. C., Shin M. S., Kim C. J., Biol. Pharm. Bull., 26, 1668-1673 (2003).

3) Cohen G. M., Biochem. J., 326, 1-16 (1997).

4) Chung B. S., Shin M. G., "The Dictionary of Korean Folk Medicine," Young Lim Sa, Seoul, 1990, p. 458.

5) Li G., Ju H. K., Chang H. W., Jahng Y., Lee S. H., Son J. K., Biol. Pharm. Bull., 26, 1039-1041 (2003).

6) Yu Y. U., Kang S. Y., Park H. Y., Sung S. H., Lee E. J., Kim S. Y., Kim Y. J., J. Pharm. Pharmacol., 52, 1163 -1169 (2000).

7) Kim N. Y., Ryu J. H., Phytother. Res., 17, 372-375 (2003).

8) Wang Z., Zhou J. B., Zhang H. J., Liu M. J., Li X., Biol. Pharm. Bull., 24, 159-162 (2001).

9) McFarlane M., Cain K., Sun X. M., Alnemri E. S., Cohen G. M., J. Cell. Biol., 137, 469-479 (1997).

10) Vogelstein B., Gillespie D., Proc. Natl. Acad. Sci. U.S.A., 76, 615619 (1979).

11) Hiroko S., Yutaka S., Motomu O., Phytochemistry, 26, 1513-1515 (1987).

12) Nakatani N., Ikeda K., Kikuzaki H., Kido M., Yamaguchi Y., Phytochemistry, 27, 3127-3129 (1988).

13) Wenkert E., Gottlieb H. E., Gottlieb O. R., Pereira M. O. S., Formiga M. D., Phytochemistry, 15, $211-214$ (1976).

14) Tanaka H., Nakamura T., Ichino K., Ito K., Phytochemistry, 28, 1905-1907 (1989).

15) Fernandes A. M. A. P., Barata L. E. S., Ferri P. H., Phytochemistry, 32, 1567-1572 (1993).

16) Wu T. S., Leu Y. L., Chan Y. Y., Yu S. M., Teng C. M., Su J. D., Phytochemistry, 36, 3773-3775 (1994).

17) Eastman A., Barry M. A., Cancer Invest., 10, 229-240 (1992).

18) Wu X., Cao S., Goh S., Hsu A., Tan B. K. H., Planta Medica, 68, $198-203$ (2002) 